\title{
Perennial crop growth in oil-contaminated soil in a boreal climate
}

\author{
Yan, Lijuan
}

2015-11-01

Yan , L , Penttinen , P J , Simojoki , A J , Stoddard , F L \& Lindström , A K 2015 , ' Perennial crop growth in oil-contaminated soil in a boreal climate ' , The Science of the Total Environment, vol. 532 , pp. 752-761 . https://doi.org/10.1016/j.scitotenv.2015.06.052

http://hdl.handle.net/10138/173362

https://doi.org/10.1016/j.scitotenv.2015.06.052

submittedVersion

Downloaded from Helda, University of Helsinki institutional repository.

This is an electronic reprint of the original article.

This reprint may differ from the original in pagination and typographic detail.

Please cite the original version. 
Perennial crop growth in oil-contaminated soil in a boreal climate

Lijuan Yan ${ }^{1}$, Petri Penttinen ${ }^{1}$, Asko Simojoki ${ }^{2}$, Frederick L. Stoddard ${ }^{3}$, Kristina Lindström ${ }^{1}$

${ }^{1}$ Department of Environmental Sciences, PO Box 65 (Viikinkaari 2a), 00014 University of

Helsinki, Helsinki, Finland

${ }^{2}$ Department of Food and Environmental Sciences, PO Box 27 (Latokartanonkaari 11), 00014

University of Helsinki, Helsinki, Finland

${ }^{3}$ Department of Agricultural Sciences, PO Box 27 (Latokartanonkaari 5), 00014 University of Helsinki, Helsinki, Finland

Corresponding author: Lijuan Yan (Mobile: +358458747988; Email: lijuan.yan@ @elsinki.fi) 


\section{Abstract}

Soil contamination by petroleum hydrocarbons is a global problem. Phytoremediation by plants and their associated microorganisms is a cost-effective strategy to degrade soil contaminants. In boreal regions the cool climate limits the efficiency of phytoremediation. The planting of oil-tolerant perennial crops, especially legumes, in oil-contaminated soil holds promise for great economic benefits for bioenergy and bio-fertilizer production while accelerating the oil degradation process. We established a multi-year field experiment to study the ecological and agronomic feasibility of phytoremediation by a legume (fodder galega) and a grass (smooth brome) in a boreal climate. In 40 months, soil oil content decreased by $73 \%-92 \%$, depending on the crop type. The oil degradation followed first-order kinetics with the reduction rates decreasing as follows: bare fallow > galega-brome grass mixture $>$ brome grass $>$ galega. Surprisingly, the presence of oil enhanced crop dry matter and nitrogen yield, particularly in the fourth year. The unfertilized galegabrome grass mixture out-yielded the $\mathrm{N}$-fertilized pure grass swards over years by an average of $33 \%$. Thus, a perennial legume-grass mixture is both ecologically and agronomically sustainable as a cropping system to alleviate soil contamination in the boreal zone, with considerable potential for bioenergy and bio-fertilizer production. 


\section{Introduction}

Soil pollution by petroleum hydrocarbons (PHCs) is an increasing problem around the world. In Finland, for example, the number of contaminated sites grew from 10,400 in 1994 to 23,850 in 2013 (Pyy et al. 2013). In situ bioremediation using indigenous microbes is an effective and lowcost strategy to degrade contaminants, but this process is limited by microbial activities, the biochemistry of enzymes, the resistant nature of the contaminants, and site-specific factors (Balba et al. 1998, Boopathy 2000). Plants are able to enhance the bioremediation of oil-polluted soil by stimulating soil microflora (Radwan et al. 1995, Suominen et al. 2000, Acharya et al. 2014). The efficiency of this phytoremediation relies on the establishment of healthy plants with sufficient shoot and root biomass growth to support the activities of a flourishing microbial consortium at the rhizosphere (Wenzel 2009). Dense cultivation of suitable crops in polluted sites was thus suggested as a promising approach for bioremediation (Radwan et al. 1995).

Nutrient deficiency, however, particularly that of nitrogen and phosphorus, often limits biodegradation in contaminated sites (Wenzel 2009). Legumes, due to their capacity for symbiotic biological nitrogen fixation, can do without $\mathrm{N}$ fertilizer input, thus assisting in the bioremediation of soils contaminated with petrochemical waste (Kamath et al. 2004, Chiapusio et al. 2007). Since bioremediation is a slow process that does not allow many disturbances of the contaminated soil, the use of perennial legumes with proper field management holds promise for accelerated oil degradation. Fodder galega (Galega orientalis Lam.), a fast-growing perennial forage legume, and smooth brome (Bromus inermis L.), a cool-season perennial sod-forming grass, are both persistent in boreal and nemoral zones and have been shown to grow well together in crop mixtures (Jasinskas et al. 2008, Kryževičienė et al. 2008). The oil tolerance and rhizoremediation potential of $G$. orientalis and its microsymbiont Neorhizobium galegae to remediate oil-contaminated soils have been demonstrated at microcosm and mesocosm scales (Suominen et al. 2000, Lindstrom et al. 2003, Jussila et al. 2006, Mikkonen et al. 2011). 
For these reasons, we set up a systematic, field-scale study on bioremediation of oil-contaminated soil coupled with plant biomass production in a boreal region. We established a multi-year field experiment to investigate the ecological suitability and potential economic benefits of fodder galega and smooth brome to grow in and bioremediate an oil-contaminated soil, and to develop an integrated and sustainable system for long-term cost-effective bioremediation practice in boreal and nemoral climates.

2. Materials and methods

\subsection{Experimental design and climatic conditions}

The field experiment was established at the Viikki Experimental Farm, University of Helsinki, Finland $\left(60^{\circ} 14^{\prime} \mathrm{N}, 25^{\circ} 01^{\prime} \mathrm{E}, 8 \mathrm{~m}\right.$ AMSL) (Table 1). It was a split-plot experimental design in four replicate blocks, with four crop treatments (pure brome grass, pure galega, galega-brome grass mixture, and bare fallow) as the main plot factor (Figure S1). The sub-plot factor was factorial combinations of oil spiked (7000 ppm) and unspiked treatments with plant growth promoting bacteria (PGPB) inoculated and un-inoculated treatments, providing 64 plots in all (4 crop treatments $\times 2$ oil treatments $\times 2$ PGPB treatments $\times 4$ replicates). The mean temperatures of the growing seasons (May - October) exceeded the long-term (1971-2000) average by $2.1^{\circ} \mathrm{C}$ in 2010 and $1.8^{\circ} \mathrm{C}$ in 2011, and the precipitation exceeded the average in 2009, 2011 and 2012 (Table 2). 2.2 Treatment preparation and field management

\subsubsection{Field management}

The site was treated with two herbicides: glyphosate (N-(phosphonomethyl)glycine), a broadspectrum systemic herbicide, before the establishment of the plots in June 2009 and Basagran® SG (165 g / 50 liter) for post emergence broad-leaved weed control in September 2009. Weeds growing in the experimental plots were removed manually in the growing season, except for a second glyphosate treatment in June 2011 in the bare fallow plots, although this treatment had no visible effect. Buffers between the blocks were maintained as weedy grassland to prevent edge effects and 
other disturbances between neighbouring plots. Mineral $\mathrm{N}$ fertilizer (60 $\mathrm{kg} \mathrm{ha}^{-1}$ of $\mathrm{N}$ as urea) was given to the pure grass plots in the summer of 2009. In May 2012, mineral N fertilizer was given only to the PGPB-treated pure grass plots. The legume plots and legume-grass mixtures received no $\mathrm{N}$ fertilizer throughout the experiment.

\subsubsection{Oil spike}

The spiking experiment was performed to evaluate the biological toxicity of the oil hydrocarbons and to assess the overall bioremediation efficiency. The oil was a mixture of used motor engine oil (Teboil Lubricants Classic Mineral Motor oil, SAE 10W-30, API SF/CD, Finland), with a density of $0.877 \mathrm{~kg} \mathrm{l}^{-1}$ at $20^{\circ} \mathrm{C}$, according to the manufacturer. The target contamination was $7000 \mathrm{ppm}(7 \mathrm{~g}$ $\mathrm{kg}^{-1}$ ) of motor oil in soil, assuming a soil bulk density of $1.0 \mathrm{~g} \mathrm{ml}^{-1}$. For each oil-spiked plot, $6 \mathrm{~kg}$ of oil was mixed with $10 \mathrm{~kg}$ of white coarse sand $(0.5-1.2 \mathrm{~mm})$, spread, and mixed into the top 20 $\mathrm{cm}$ of soil in the oil-treated plots with a rotary tiller on 17 June 2009. Ten $\mathrm{kg}$ of pure sand without oil was mixed into the top $20 \mathrm{~cm}$ of soil in the control plots.

\subsubsection{Seed co-inoculation and sowing}

Before sowing, commercial seeds of G. orientalis cv. 'Gale' (Naturcom Oy, Ruukki, Finland) and B. inermis cv. 'Lehis' (Jõgeva Plant Breeding Institute, Estonia) were surface-sterilized before inoculation with bacteria. To ensure biological nitrogen fixation, all galega seeds were inoculated with Neorhizobium galegae strain HAMBI 540 (University of Helsinki, Helsinki, Finland). Two plant growth promoting root-colonizing bacteria strains, Pseudomonas trivialis 3Re27 (Graz University of Technology, Graz, Austria) and Pseudomonas extremorientalis TSAU20 (National University of Uzbekistan, Uzbekistan), were inoculated onto the seeds of both crops as described by Egamberdieva et al. (2010). The PGPB-free seeds were used as controls. The inoculated seeds were mixed with peat prior to sowing. The seeds were manually sown and lightly covered by raking. The first sowing was done on 7 July 2009. Brome grass was sown at $35 \mathrm{~kg} \mathrm{ha}^{-1}$, galega at $25 \mathrm{~kg} \mathrm{ha}^{-1}$, and 
the combination at $26 \mathrm{~kg} \mathrm{ha}^{-1}$ of brome grass and $6 \mathrm{~kg} \mathrm{ha}^{-1}$ of galega to give a 75:25 ratio. Due to a poor initial growth of the galega, it was resown in May 2010.

\subsection{Crop biological measurements and data handling}

The crops were cut with a forage harvester twice in a growing season over three successive growing seasons (2010-2012). The first cut was done when flowering began in late June and the second cut was done in late August, these being typical harvesting times for hay or silage. The total fresh biomass of crops (W) was weighed on the day of harvesting and the species in the mixtures were separated. The proportion of galega $(\mathrm{G} \%)$ was estimated on the basis of fresh weight in each mixture plot. Crop dry matter content (DM\%) was determined by drying to the constant mass at $105{ }^{\circ} \mathrm{C}$. The DM yield $\left(\mathrm{t} \mathrm{ha}^{-1}\right)$ of each harvest was calculated as follows: $\mathrm{DM}$ yield $=\mathrm{DM} \% \times \mathrm{W}$. The total DM yield in the mixture plots was the sum of both crops. The annual DM yields for the crops were the sum of the DM yields of two harvests per year.

For chlorophyll measurement, the youngest fully expanded blades were selected. The mean of 1020 readings per plot from the portable chlorophyll meter (SPAD-502, Minolta, Japan) was obtained per plot on every 15 June and 15 July each year from 2010 to 2012 (20 readings per monoculture plot, and 20 readings from brome grass and at least ten from galega per mixture plot). We did one additional SPAD reading on 15 August 2012. SPAD readings for mixture plots was estimated by: mixture SPAD reading $=\mathrm{SPAD}_{\mathrm{B}} \times(1-\mathrm{G} \%)+\mathrm{SPAD}_{\mathrm{G}} \times \mathrm{G} \%$, where the subscripts $\mathrm{G}$ and $\mathrm{B}$ refer to galega and brome grass, respectively. The annual SPAD reading of each plot was calculated as the average of readings measured in June and July in each year.

The $\delta^{15} \mathrm{~N}\left({ }^{15} \mathrm{~N}\right.$ natural abundance) technique was used to determine biological $\mathrm{N}$ fixation (BNF) in the galega, according to Unkovich et al. (2008). The brome grass in the same soil was used as the non-N-fixing reference plant to determine the $\delta^{15} \mathrm{~N}$ of the plant-available $\mathrm{N}$ in the soil. About 100 grams of each crop shoot sample were dried at $60{ }^{\circ} \mathrm{C}$ overnight before the determination of total carbon $(\mathrm{C} \%)$ and nitrogen content $(\mathrm{N} \%)$ by the Dumas combustion method with a VarioMax $\mathrm{CN}$ - 
analyzer (Elementar Analysensysteme GmbH, Hanau, Germany), followed by the stable isotope abundance $\left(\right.$ atom $\%{ }^{15} \mathrm{~N}$ ) by mass spectrometry at the James Hutton Institute, Scotland, UK. Four replicated dry grass shoot samples taken from the mixture plots were pooled before determination of the atom $\%{ }^{15} \mathrm{~N}$. The atom $\%{ }^{15} \mathrm{~N}$ of the PGPB-treated legume shoot samples harvested in 2010 was determined. The total $\mathrm{N}$ yield $\left(\mathrm{kg} \mathrm{ha}^{-1}\right)$ of monoculture plots was calculated as $\mathrm{N}$ yield $=\mathrm{N} \% \times$ $\mathrm{DM} \% \times \mathrm{W}$. The total $\mathrm{N}$ yield $\left(\mathrm{kg} \mathrm{ha}^{-1}\right)$ of crops in mixture plots per cut was estimated as follows: mixture $\mathrm{N}$ yield $=\mathrm{N}_{\mathrm{B}} \% \times \mathrm{DM}_{\mathrm{B}} \% \times \mathrm{W}_{\mathrm{B}} \times(1-\mathrm{G} \%)+\mathrm{N}_{\mathrm{G}} \% \times \mathrm{DM}_{\mathrm{G}} \% \times \mathrm{W}_{\mathrm{G}} \times \mathrm{G} \%$. Since the $\mathrm{N} \%$ of each crop in mixture plots was not measured separately in 2010, the total $\mathrm{N}$ yield $\left(\mathrm{kg} \mathrm{ha}^{-1}\right)$ per cut in this year was therefore calculated as follows: mixture $\mathrm{N}$ yield in $2010=\mathrm{N} \% \times \mathrm{DM}_{\mathrm{B}} \% \times \mathrm{W}_{\mathrm{B}} \times(1-$ $\mathrm{G} \%)+\mathrm{N} \% \times \mathrm{DM}_{\mathrm{G}} \% \times \mathrm{W}_{\mathrm{G}} \times \mathrm{G} \%$. Because the second harvests were not done on the same dates in each year, the annual crop $\mathrm{C}$ content, $\mathrm{N}$ content and $\mathrm{C}: \mathrm{N}$ ratio of each plot were calculated for data analysis, as the average of values measured from two harvests per year. The sample natural abundance expressed as parts per thousand relative to atmospheric $\mathrm{N}_{2}$ was calculated as follows: $\delta^{15} \mathrm{~N}(\%)=\left(\right.$ sample atom $\%{ }^{15} \mathrm{~N}-$ atom $\%{ }^{15} \mathrm{~N}$ in the atmosphere $) /$ atom $\%{ }^{15} \mathrm{~N}$ in the atmosphere $\times$ 1000, where the atom $\%{ }^{15} \mathrm{~N}$ in the atmosphere is 0.3663 (Unkovich et al. 2008). The proportion of legume shoot $\mathrm{N}$ derived from atmospheric $\mathrm{N}_{2}(\% \mathrm{Ndfa})$ was calculated as follows: $\% \mathrm{Ndfa}=\left(\delta^{15} \mathrm{~N}\right.$ of reference plant $-\delta^{15} \mathrm{~N}$ of $\mathrm{N}_{2}$-fixing legume $) /\left(\delta^{15} \mathrm{~N}\right.$ of reference plant - 'B' value $) \times 100$, where 'B' value, the $\delta^{15} \mathrm{~N}$ of shoots of the Neorhizobia galegae-inoculated galega that is fully dependent upon $\mathrm{N}_{2}$ fixation and sampled at the same growth stage as the field plants, is the correction factor to adjust for isotopic fractionation by the legume (Unkovich et al. 2008). However, a proper 'B' value for the shoot of fodder galega is lacking. Carlsson et al. (2006) proposed that the variation of 'B' value in relation to plant age and overwintering with the ${ }^{15} \mathrm{~N}$ natural abundance method was small compared to the variation that occurred between different Rhizobium strains. We therefore used the same 'B' value (-1.40) averaged from the 'B' values of all Rhizobium strains and plant age for shoots of three temperate forage legume species (-1.2 in Trifolium hybridum, -1.3 in T. pratense and 
-1.7 in $T$. repens) grown in northern Scandinavia to estimate the \%Ndfa in galega shoots in successive growing seasons, according to the recommendations from Unkovich et al. (2008). The seed $\mathrm{N}$ content was negligible in the long period cultivation of the legume (Carlsson et al. 2006). The biologically fixed $\mathrm{N}(\mathrm{BNF})$ yield $\left(\mathrm{kg} \mathrm{ha}^{-1}\right.$ of $\left.\mathrm{N}\right)$ in the legume per legume-cropped plot was calculated as BNF yield $=\mathrm{DM}$ yield of the legume $\times \mathrm{N} \%$ of the legume $\times \% \mathrm{Ndfa} / 100$. The annual $\mathrm{N}$ yields and the annual BNF yield were the sum of the two harvests per year. The annual proportion of legume shoot $\mathrm{N}$ derived from atmospheric $\mathrm{N}_{2}$ (annual $\% \mathrm{Ndfa}$ ) was calculated as follows: annual $\% \mathrm{Ndfa}=$ annual $\mathrm{BNF}$ yield $/$ annual $\mathrm{N}$ yield in the shoot of the galega $\times 100$. 2.4 Soil sampling and physiochemical analysis

\subsubsection{Soil sampling}

The soil was sampled six times (Table 3). On each occasion, sixteen sub-samples were taken from the topsoil $(0-25 \mathrm{~cm})$ in each plot using an auger with a diameter of $2 \mathrm{~cm}$. The sampling was designed so as not to disturb the plants. Since the germination of galega in the first year was poor, the samples were taken under the canopy in the monoculture plots rather than from bare soil. In the mixture plots, two of sixteen sub-samples were taken under the galega canopy. The 16 sub-samples of each plot were combined to one composite sample, mixed, sieved through a $5 \mathrm{~mm}$ mesh, put in a plastic bag and stored at $-20^{\circ} \mathrm{C}$ until the analysis.

\subsubsection{Soil chemical analysis}

After thawing, the samples were air-dried at room temperature (1 week), ground by hand and sieved through a $2 \mathrm{~mm}$ mesh before analysis. Soil properties (electrical conductivity, $\mathrm{pH}$ in water, and total C and N) were measured from three repeated sample sets in July 2009, November 2010 and May 2012 respectively. Electrical conductivity (EC) and soil pH were measured in a soil-water suspension 1:2.5 (v:v). EC was measured from the solution part of the suspension using a conductivity meter (MeterLab ${ }^{\mathrm{TM}}$ CDM210, Radiometer Analytical), and the $\mathrm{pH}$ was measured by a pH-meter (SCHOTT CG842, SI Analytics) after mixing the suspension with a glass rod. Soil dry 
matter content (DMs) was determined by drying to the constant mass at $105^{\circ} \mathrm{C}$. Soil total $\mathrm{C}$ and $\mathrm{N}$ contents were measured using the VarioMax CN-analyzer and corrected to the oven-dry basis.

\subsection{Determination of oil concentration}

To monitor the oil degradation over time, we estimated the oil concentration of each oil spiked plot based on the difference of total solvent extractable material (TSEM) concentration between the plot and the average of 4 to 5 randomly selected control plots at each sampling time. The hydrocarbons were extracted from thawed soil samples according to the modification of the ISO 16703:2004 method by Jørgensen et al. (2005). Ten grams of homogenized moist soil samples were weighed (Gs, $0.001 \mathrm{~g}$ accuracy) and dissolved in $10 \mathrm{ml}$ of retention time window solution (1 L HPLC-pure $n$-heptane $+30 \mu \mathrm{l} n$-decane $+30 \mathrm{mg} n$-tetracontane) and $20 \mathrm{ml}$ HPLC-pure acetone by ultrasonication for $30 \mathrm{~min}$. A blank sample (without soil) was prepared on every extraction day. Acetone was removed by duplicate washing of the extract with deionized water at the ratio of 1:1, followed by centrifugation $(1600 \times \mathrm{g})$ for $5 \mathrm{~min}$. The upper organic phase was removed to a new glass tube and dried with $0.1 \mathrm{~g}$ of water-free $\mathrm{Na}_{2} \mathrm{SO}_{4}$ (dried at least $4 \mathrm{~h}$ at $550{ }^{\circ} \mathrm{C}$ ). The water-free hydrocarbon extract was removed to a new $10 \mathrm{ml}$ storage glass tube and carefully sealed and stored at $-20{ }^{\circ} \mathrm{C}$.

TSEMs, consisting of all the hydrocarbons extracted from soil samples (Wang and Fingas 1997), were measured gravimetrically immediately after extraction according to Mikkonen et al. (2012). Generally, TSEM values of the control plots remained rather stable over time with an average of $0.83 \mathrm{~g} \mathrm{~kg}^{-1}$ soil dry matter.

\subsection{Statistical analysis of data}

All soil chemical and plant data were analyzed using SPSS (version 20, IBM Inc., Armonk, NY, USA). We used repeated measures split-plot analysis of variance (RM ANOVA) with the sampling time as the repeated factor (within-subject factor) to test the overall between- and within- subjects effects (sphericity assumed) on soil properties, oil concentration and crop physiological characters. 
Crop treatment as the main plot factor, and oil and PGPB treatments as the subplot factors were fixed factors, while block (replicate) was a random factor. Thus, crop was tested against the interaction term crop $\times$ block to take out the effect of the main plot from the residual variance so it does not skew the error variance of the subplot stratum. Oil, PGPB and their remaining interactions were tested against the subplot error mean square.

Since PGPB resulted in no significant impact on soil parameters and oil concentration for the first four sampling times (data not shown), we sampled soils only from PGPB-untreated plots afterwards. Similarly, the $\delta^{15} \mathrm{~N}$ was measured only from PGPB untreated plots in 2011 and 2012. Therefore the analyses of variance for soil parameters, oil concentration, annual \%Ndfa and annual BNF yield in the legume shoot were carried out and reported only for the PGPB-untreated plots. To further test the between-subjects effects of 1) the oil treatment and crop treatment on soil chemical properties, 2) the crop treatment on oil concentration and 3) the oil treatment and PGPB treatment on crop physiological characteristics in separate years, the split-plot univariate analysis of variance (UV ANOVA) was applied. Means of oil concentration between different crop treatments and means of physiological properties between different crops were compared using the Tukey HSD multiple pairwise comparison test, whereas means in relation to different sampling times were compared using Bonferroni multiple pairwise comparison test in SPSS. All differences were concluded significant at $p \leq 0.05$. Kinetic modelling was performed to estimate the rates of oil degradation in different cropping systems, according to Snoeyink and Jenkins (1980).

3. Results

\subsection{Crop performance in bioremediation cropping systems}

\subsubsection{Crop growth in clean soil}

Crop physiological properties (SPAD readings, $\mathrm{C}, \mathrm{N}$ content, $\mathrm{C}: \mathrm{N}$ ratio) were species-dependent and were not affected by oil treatment (Table 4). The time $\times$ crop interaction on crop physiological properties was evident (Table 4). SPAD readings of galega rose from year to year, while those of 
brome grass decreased (Table 4). Within each year, SPAD values of galega fluctuated, while those of the brome grass decreased (data not shown). Crop N content dropped from 2010 to 2011 in brome grass and increased each year in galega, leading to opposite changes in the $\mathrm{C}: \mathrm{N}$ ratio (Table 4).

Crop dry matter and $\mathrm{N}$ yield differed in different cropping systems and in different years (Table 5). Each year over the three years, the legume-grass mixture out-yielded (DM basis) the pure stands of galega by an average of $2.31 \mathrm{Mg} \mathrm{ha}^{-1}(32 \%)$ and of brome grass by $2.41 \mathrm{Mg} \mathrm{ha}^{-1}(34 \%)$ in clean soil (Table 5, Tukey HSD test, $p<0.01$ ). Brome grass yield in the mixture plots exceeded the yields of the corresponding pure grass plots in each year (data not shown). The galega yield more than doubled in 2011 and 2012 over that in 2010. Yield of the brome grass was higher in the June cut than in the August cut, but that of the galega showed little difference between cuts (data not shown). An average of 233, 100 and $156 \mathrm{~kg} \mathrm{ha}^{-1}$ of $\mathrm{N}$ (Table 5) was harvested annually from the aboveground parts of pure galega, pure brome grass and their mixture, respectively from the oil-unspiked plots, over three years. The $\mathrm{N}$ yields of both brome grass and mixture remained stable over years, whereas that of pure galega more than doubled after the first year (Table 5).

The parameters of $\delta^{15} \mathrm{~N}, \% \mathrm{Ndfa}, \mathrm{BNF}$ yield and $\mathrm{BNF}$ yield / galega DM yield were measured to evaluate the biological nitrogen fixation efficiency of the legume Galega orientalis in the bioremediation experiment. Neither the crop (monoculture or mixture) nor the oil treatment had any significant influence on the $\delta^{15} \mathrm{~N}$ of galega in PGPB-free plots (data not shown). Nevertheless, the $\delta^{15} \mathrm{~N}$ values of the galega changed with time, with the values of $0.61,2.10,0.65,-0.43,-0.08$ and 0.50 from the six harvests, respectively. The $\delta^{15} \mathrm{~N}$ in the pooled shoot sample of the brome grass was $4.68,5.53,4.20,3.08,3.84$ and 3.30 in the six harvests in the oil-untreated plots and $6.38,6.42$, 3.94, 1.54, 4.09 and 3.68 in the oil-treated plots. The proportion of $\mathrm{N}$ derived from the atmosphere (\% Ndfa) was higher in the galega in the mixture than in the pure stands over years (RM ANOVA, $p$ $=0.051$ ), especially in 2012 (Table 6). The annual values of \%Ndfa did not differ between 2010 and 
2011, and significantly increased in 2012 (Bonferroni multiple pairwise comparison test, $p<0.01$ ). The annual BNF yield of pure galega continuously and greatly increased from 2010 to 2012 (Table 6), whereas the BNF yield of galega in mixture significantly decreased in 2011 before it achieved its highest value in 2012 (Table 6). Galega in mixture plots fixed more atmospheric N per unit of dry matter yield than its monoculture counterparts (26.3 vs $20.5 \mathrm{~g} \mathrm{~kg}^{-1}$ in clean soil), especially after it achieved its stable growth in 2012.

\subsubsection{Toxicity assessment of oil contamination on crop growth}

Oil spiking significantly enhanced the overall crop performance, in spite of a slight decrease of total C content in brome grass in 2010 (UV ANOVA, $p<0.05$, data not shown) and a reduction of \%Ndfa in galega and mixture in 2011 (Table 6). Oil contamination was associated with an increase in the annual crop dry matter yield of $494 \mathrm{~kg} \mathrm{ha}^{-1}(6.7 \%)$ in brome grass-, $992 \mathrm{~kg} \mathrm{ha}^{-1}$ $(13.8 \%)$ in galega- and $580 \mathrm{~kg} \mathrm{ha}^{-1}(6.1 \%)$ in mixture-cropped plots throughout the experiment (Table 5). The positive effect of oil treatment on crops was also seen in the elevated $\mathrm{N}$ yield, up by $19.0 \mathrm{~kg} \mathrm{ha}^{-1}(11.7 \%)$, annually (RM ANOVA, $\left.p<0.01\right)$. The oil enhancement of $\mathrm{N}$ yield was greatest in pure galega plots, $39 \mathrm{~kg} \mathrm{ha}^{-1}(16.7 \%)$ higher in oil-spiked plots than in clean controls (Table 5). In 2011, although the \%Ndfa showed reductions by oil contamination (Table 6), the $\mathrm{N}$ yield of the legume was still $34 \mathrm{~kg} \mathrm{ha}^{-1}(11.7 \%)$ higher in oil-spiked plots than in clean controls (Table 5). The oil enhancement of crop growth was more obvious in 2012 than the previous two years, characterized by the significant increase of DM yield, \% Ndfa, BNF and $\mathrm{N}$ yield, especially in the pure galega plots (Table 5 and Table 6).

\subsubsection{PGPB effect on crop growth and BNF}

Generally, the effect of PGPB on crop physiological properties (Table 4) and DM yield (Table 5) was minor, but it enhanced BNF in the legume-cropped plots (Table 7). The PGPB enhancement was by the large shown as the increase of $\%$ Ndfa, especially in the mixture plots. The $\% \mathrm{Ndfa}$ in PGPB-treated plots was $13.5 \%(19 \%)$ higher than in PGPB-untreated plots in the first cut in 2010 
and $16.1 \%(31 \%)$ higher in the second (Table 7). PGPB treatment increased the BNF yield in legume shoots by $25.6 \mathrm{~kg} \mathrm{ha}^{-1}(37 \%)$ in pure galega plots and $8.3 \mathrm{~kg} \mathrm{ha}^{-1}(45 \%)$ in mixture plots relative to the corresponding PGPB-untreated plots in 2010 (Table 7). The positive effect of PGPB treatment was also found in crop $\mathrm{N}$ yield in 2012 (Table 5), leading to a lower crop C:N ratio (data not shown); however, due to the fertilization of the PGPB-treated pure grass plots in that year, the results were not comparable.

\subsection{Impacts of oil and crop treatment on soil chemical properties}

Oil contamination significantly affected soil total $\mathrm{C}$ content, $\mathrm{C}: \mathrm{N}$ ratio and electrical conductivity, but had no influence on total $\mathrm{N}$ content and pH (Table 8). In July 2009, oil addition significantly increased the soil total $\mathrm{C}$ by $3.69 \mathrm{~g} \mathrm{~kg}^{-1}(16.6 \%)$ and $\mathrm{C}: \mathrm{N}$ ratio by $1.6(14.7 \%)$ relative to the control soil. Soil total C significantly decreased with time as the oil was degraded, but was still higher than in the control plots in May 2012 (univariate ANOVA, $p<0.01$ ). The average soil C:N ratio in the field was generally low $(<11: 1$ in control plots, $<12: 1$ in oil treated plots), and was significantly affected by the oil $\times$ crop interaction. The galega soil showed the lowest $\mathrm{C}: \mathrm{N}$ ratio $(10.5: 1)$ in clean control plots, but the highest value (12.1:1) in oil-treated plots. Oil treatment significantly decreased soil EC by $11.7 \mu \mathrm{S} \mathrm{cm}^{-1}$ (17.6\%) (Table 8). The EC values dropped significantly in the control plots over time, but remained stable in oil-treated plots (time $\times$ oil interaction). Soil $\mathrm{pH}$ decreased slightly with time with an average value of 6.4. None of the treatment factors or their interactions affected soil total $\mathrm{N}$ content, which averaged $2.21 \mathrm{~g} \mathrm{~kg}^{-1}$. Crop treatment had no impact on soil chemical properties, but the interactions between crop treatment and other factors on soil properties were evident (Table 8). For example, the time $\times$ crop $\times$ oil interaction had a significant effect on soil EC. In oil treated soils, EC values increased in bare fallow and brome grass plots but decreased in galega and mixture plots. In clean soils, EC values in galega and mixture plots decreased sharply in 2010 before a slight increase in 2012 whereas EC values in brome grass plots decreased continuously with time (data not shown). 


\subsection{Oil degradation pattern}

The oil concentration decreased over time (Figure 1). At the end of the experiment, $92 \%$ of the

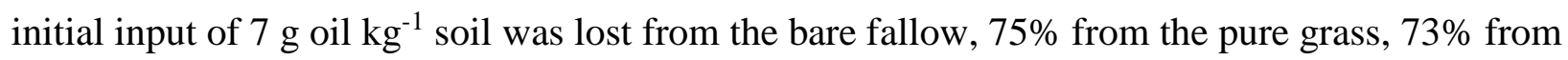
the pure legume and $77 \%$ from the mixture plots. Oil degradation was most intense during the first month, as shown by a reduction of oil concentration by $43 \%$ in bare fallow, $40 \%$ in the pure grass plots, $34 \%$ in the pure galega plots and $52 \%$ in the mixture plots. The second significant loss of oil occurred during the second growing season, 2010 (months 12-18). Afterwards, oil concentration remained relatively stable with slight fluctuations until the end of the experiment. Oil degradation differed among crop treatments. The average oil concentration in the bare fallow plots was lower than that in the pure legume plots by $0.90 \mathrm{~g} \mathrm{~kg}^{-1}$ soil DM (25\%) throughout the experimental period (Tukey HSD test, $p<0.05$ ).

The oil degradation in all plots followed a typical first-order kinetic pattern, in which the oil degradation rate was proportional to the oil concentration. The coefficients of determination $\left(\mathrm{R}^{2}\right)$, ranging from 0.379 to 0.571 (Table 9), were all statistically significant. The first-order degradation rate constants $(k)$ in different treatments followed the order bare fallow $>$ mixture $>$ brome grass $>$ galega (Table 10). According to this model, 15 to 24 months are required to halve the hydrocarbon concentration in this region, depending on the crop type (Table 10). Nevertheless, the initial oil concentrations estimated in the first-order kinetic models were lower than the designed oil input value $\left(7 \mathrm{~g} \mathrm{~kg}^{-1}\right)$ by an average of $2.02 \mathrm{~g} \mathrm{~kg}^{-1}(29 \%)$.

\section{Discussion}

\subsection{Evaluation of the values of legume-grass mixture cultivation in a boreal climate}

We studied the ecological suitability and agronomic productivity of fodder galega and brome grass through the assessment of adaptation ability, BNF efficiency and DM production in a boreal region. Both the legume G. orientalis and grass $B$. inermis are suitable to grow in boreal regions as potential bioenergy swards. The slow initial growth of the galega, reaching stable production in the 
second or third year after sowing as indicated by the increasing values of $\mathrm{N}$, chlorophyll, $\mathrm{C}$ content, DM yield and BNF yield, agrees with previous studies (Adamovich 2001, Halling et al. 2002, Singer et al. 2003, Kryževičienė et al. 2008, Zolotarev 2010). In addition to the plant's intrinsic growth pattern, the cool environment might have limited the nodulation and BNF activities of the microsymbiont Neorhizobium galegae in the first year. The rapid germination of the brome grass in the seedling year in this boreal field accorded with expectation (Global Invasive Species Database 2010). The continuous stable growth of the grass demonstrated its excellent adaptation to the boreal conditions.

The unfertilized galega-brome mixture out-yielded the $\mathrm{N}$-fertilized pure grass swards over years by an average of $34 \%$, although fewer seeds were sown. This finding is in accordance with previous field studies (Halling et al. 2002, Adamovich et al. 2007, Kryževičienè et al. 2008), where it was attributed to the substantial BNF capacity of fodder galega. Our data demonstrated that BNF was more efficient in the mixture, with a higher \%Ndfa and a higher ratio of BNF yield to legume DM yield than in pure legume stands, bearing in mind that no alterations of soil total $\mathrm{N}$ content occurred between different crop treatments. This result was attributable to an effective legume-rhizobium symbiosis, where BNF is a product of the interaction between soil $\mathrm{N}$ environment and overall legume growth (Lindström 1984, Unkovich and Pate 2000). Assuming that soil was the only N source for grass uptake without directional $\mathrm{N}$ transfer from the legume to the grass, the $\delta^{15} \mathrm{~N}$ values of the reference grass would be about the same throughout the experimental period. Nevertheless, we observed decreasing $\delta^{15} \mathrm{~N}$ values and higher yield of the brome grass in the mixture plots over time, indicating $\mathrm{N}$ translocation from the legume to the grass, probably via litter decomposition. Fodder galega increased the amount of bioavailable nutrients in soil after it achieved its stable growth, indicated by the elevated soil electrical conductivity in pure galega plots in 2012. Similarly, a fallow field turfed with fodder galega was found to accumulate bioavailable nutrients $\mathrm{P}, \mathrm{K}$ and 
$\mathrm{Mg}$ in soil, due to dissolution of nutrients from less soluble compounds and subsequent nutrient mobilization by soil microbes (Sienkiewicz et al. 2011).

Given its adaptation ability, substantial BNF capacity, productive longevity and effects on soil fertility, the galega-brome grass mixture has potential for bioenergy production in boreal regions. In addition, its $\mathrm{C}: \mathrm{N}$ ratio (27:1) was close to the known optimal value $(25: 1)$ for microbial decomposition (Ndegwa and Thompson 2000). Together with the substantial N yield, the legumegrass mixture residues can be converted into high-value fertilizer by soil fauna and microflora. Thus, the legume-grass mixture has both agronomic and ecological merits, indicating its suitability as a bioenergy cropping system for boreal regions.

4.2 Overall assessment of the legume-cropping bioremediation system

\subsubsection{Evaluation of soil chemical composition and oil dissipation}

The aim of this work was to evaluate the effectiveness of the bioremediation cropping systems, complex interactions between crops, soil and contaminants during oil contamination and degradation. Soil quality is dependent on the interactions between soil physical, chemical and biological properties (Dexter 2004). Oil contamination has a great impact on soil quality and in turn, soil quality directly affects the effectiveness and efficiency of bioremediation. The amount of oil used was sufficient to be detected in clear increases in total soil C, C:N ratio and TSEMs. Soil electrical conductivity, which is influenced by properties of the pore-filling contaminants at the interface region of a soil (Börner et al. 1993), decreased in oil-spiked plots. The lack of effect of oil on other soil properties such as $\mathrm{pH}$ and total $\mathrm{N}$ content is attributable to the effective buffering of the soil system.

Most laboratory or field experiments spiked with different types of hydrocarbon mixtures are modelled by first-order kinetics (Jørgensen et al. 2000, Nocentini et al. 2000, Van Gestel et al. 2003), whereas only a few studies (Sarkar et al. 2005) have found second-order kinetics necessary. The coefficients of determination $\left(\mathrm{R}^{2}\right)$ were modest but all statistically significant, indicating that 
our oil degradation data fit reasonably to the first-order kinetic model, although there was wide variation in oil concentration between replicates. The kinetic parameters based on the first-order degradation model revealed a higher oil reduction rate in bare fallow and mixture and a lower rate in monocultures. The high degradation rate constant of oil degradation in the bare fallow demonstrated that the indigenous microorganisms were capable of degrading hydrocarbons in soil. Crop treatments had a negative effect on oil dissipation, particularly the pure galega, under which oil reduction was slower than in the bare fallow, throughout the experiment. This phenomenon contrasts with other studies where crops were found to stimulate microbial oil-degradation activities at the rhizosphere, because root exudates comprised of organic acids, sugars, amino acids and aromatics with changeable composition or amount are excellent primary $\mathrm{C}$ and energy substrates for organisms to degrade organic pollutants (Miya and Firestone 2001, Singer et al. 2003, Rentz et al. 2005, Kawasaki et al. 2012). The soil microorganisms may favour easily degradable plant derived compounds over oil hydrocarbons as energy and C substrates. Another possible reason for this result lies in the oil determination method. A no-till management system had the greatest seasonal fluctuation of soil organic carbon (Wuest 2014). The solvent co-extracted natural, carbon-rich compounds such as waxes and chlorophyll from the plants might have contributed to soil TSEMs, elevating the estimates of oil concentration in the vegetated plots. The fluctuation in TSEM values after 18 months of oil degradation may have been due to seasonal inputs of plant residues and root exudates. The determination of the composition of different hydrocarbon groups, as presented by Wang and Fingas (1997), is needed to further confirm this assumption.

The initial rapid loss of approximately $\sim 42 \%$ of oil in the first month is in line with previous field studies, where removal of motor lubricating oil was most rapid during the first month and then declined with time (Jørgensen et al. 2000). Joner et al. (2004) attributed the rapid oil dissipation to priming effects following soil excavation and homogenization at the initial stage when neither readily available $\mathrm{C}$ (root-derived organic materials) nor mineral nutrients were limiting for 
biodegradation of hydrocarbons. Nevertheless, abiotic loss of a large proportion of light volatile hydrocarbons was likely to account for the initial rapid oil dissipation and the experimental area smelled strongly of oil for several weeks after spiking. Margesin and Schinner (1997) demonstrated that about $30 \%$ of diesel oil was eliminated due to abiotic loss at $10{ }^{\circ} \mathrm{C}$ in newly contaminated soils. Similarly, $30 \%$ of hydrocarbon was assumed to be lost by physical weathering (vaporization or dissolution) in the first year after the Exxon Valdez spill in Alaska (Bragg et al. 1994). In the first order-kinetic models the estimated initial oil concentrations were lower than the real input value. Plausibly the estimated concentrations were the starting points of the biodegradation process after evaporation. In the present experiment, the second significant oil dissipation occurred during the 2010 growing season, probably due to the biodegradation of easily available hydrocarbons by indigenous soil microorganisms. Afterwards, oil degradation slowed down.

We achieved a more than $70 \%$ reduction of oil in the vegetated plots and more than $90 \%$ in bare fallow in the three-year field experiment. Incomplete biodegradation of complex hydrocarbon mixtures with a stabilized residual concentration prevails in bioremediation projects (Nocentini et al. 2000). When the biodegradation has reached the residual concentration, further intensive treatment is rarely useful even when optimal biodegradation conditions are provided (Huesemann 1997, Nocentini et al. 2000). The residual oil in the soil was expected, as the resistance of hydrocarbons to biodegradation and extraction increases with time in soil (Hatzinger and Alexander 1995). There are two major recognized causes of incomplete biodegradation, both of which emphasize the poor bioavailability of aged hydrocarbons to microbes: 1) the sequestration of hydrocarbons within the pores of soil aggregates, and 2) the inherently recalcitrant characteristics of residual fractions (Huesemann 1997). Only the latter aspect poses a chronic threat to the environment. Although the exact composition of hydrocarbon fractions in the newly spiked motor oil and the residues was not determined, one would expect to find the heavier distillates among the remaining compounds at the end of a bioremediation experiment (Sarkar et al. 2005). The different 
petroleum hydrocarbon fractions could be quantified (Wang and Fingas 1997, Mikkonen et al. 2011), but it was suggested that the total petroleum hydrocarbons (TPHs) an insufficient measure to monitor soil remediation due to accumulation of polar and complexed degradation products (Mikkonen et al. 2012). Since we were interested in monitoring the whole remediation process, we did not attempt to quantify individual fractions.

Furthermore, some plants are able to directly remediate oil-contaminated soils by several mechanisms, including hydraulic control, volatilization, stabilization, transformation, degradation and rhizodegradation (Kamath et al. 2004). We lack evidence to identify the direct oilphytoremediation capacity of these two crops in the field, although both galega and brome grass remained healthy and productive under oil stress.

\subsubsection{Crop growth under oil stress}

Limitations to the growth of plants and metabolic activities of microbes may arise from the severity of contamination and the heterogeneous nature of soil (Acharya et al. 2014). Certain annual plants were able to survive in moderately to weakly contaminated sites with oil content below $10 \%$ by weight (Radwan et al. 1995). Phytotoxicity assessment of oil contamination should thus take place prior to the implementation of a bioremediation project. Previous greenhouse experiments found that the growth, nodulation and BNF of fodder galega were normal in soil contaminated with either fuel or diesel oil (3000 ppm), except that biomass production was reduced in the presence of fuel oil (Suominen et al. 2000, Mikkonen et al. 2011). Our field data demonstrated that used motor oil (7000 ppm) was insufficient to stress the growth of the both crops despite a minor loss of crop total $\mathrm{C}$ in brome grass in 2010 and of \% Ndfa in galega in 2011. The normal growth and symbiotic functions of the galega under oil stress in the field validated the applicability of the above mentioned greenhouse findings.

Conversely, the presence of oil, to our surprise, markedly enhanced the crop dry matter yield, BNF efficiency and $\mathrm{N}$ yield, especially in 2012. More interestingly, the effect of the oil treatment was 
particularly significant on the legume. As discussed earlier, BNF, a product of the interaction between soil N environment and overall legume growth (Lindström 1984, Unkovich and Pate 2000), was influenced by the interactions between the legume, the rhizobium, soil and the hydrocarbons in oil contaminated plots. Mikkonen et al. (2011) attributed this positive post-effect of oil addition on the growth of galega to the reduced phytotoxicity following the loss of easilydegradable alkanes that are more toxic to plants than aromatics. The subsequent recovery of soil microbial activities, especially those of the rhizobia, from oil inhibition might have contributed to the increased BNF, DM yield and N yield of the legume. Earlier experiments also found that oil treatment had positive effects on soil in two aspects: 1) enhancement of biochemical and microbial activities with regard to higher microbial biomass $\mathrm{C}$ and metabolic activities (Caravaca and Roldán 2003, Mikkonen et al. 2011), and 2) the induction of 15-fold greater soil porosity in the range of transmission pores, which are essential for the growth of plant principal roots, for drainage and for aeration (Caravaca and Roldán 2003). Thus the biological, chemical and physical enhancement of soil quality by oil contamination might have together induced vigorous crop growth, despite the initial inhibition on BNF of the legume-rhizobium symbiotic system. Hence, the combination of these two perennial crops is a good candidate to achieve considerable output while alleviating soil contamination in boreal soils.

\subsubsection{PGPB effect}

In this experiment, we aimed to evaluate the effects of plant growth promoting bacteria on soil, crop growth and oil reduction. Co-inoculation of fodder galega with its specific rhizobia and plant growth promoting Pseudomonas strains improved plant growth, nodulation and $\mathrm{N}$ content in a pot experiment (Egamberdieva et al. 2010). In the present study, the enhancement by Pseudomonas strains on the BNF of fodder galega in regard to \% Ndfa and BNF yield was evident in 2010, but there was little evidence of such an effect on the overall crop DM production. In Estonia, high $\mathrm{N}$ fertilization rate reduced the role of fodder galega in the galega-grass mixture swards (Lättemäe et 
al. 2013). We can therefore hypothesize that the enhancement of $\mathrm{N}$ fixation by PGPB was mainly driven by the nutrient requirement of the legume. When there is sufficient soil mineral $\mathrm{N}$ for the growth of the legume, BNF would be inhibited. In the presence of resource competition from the grass in the mixture plots, the PGPB took effect to improve the BNF in the legume.

Neither soil properties nor oil concentration responded to the PGPB inoculation (data not shown) in our field, in contrast to other studies where PGPB enhanced the rhizoremediation of polluted soils (Pajuelo et al. 2011, Vershinina et al. 2012, Bhattacharyya and Jha 2012). However, the oil tolerance ability of PGPB strains, the local field factors and the hydrocarbon composition were different from these studies. Long-term monitoring should be applied to reveal the effects of PGPB on perennial crops.

\section{Conclusions}

Bioremediation by indigenous organisms is considered a cost-effective strategy to reclaim contaminated sites. In our bioremediation field experiment, different cropping systems exhibited the same first-order kinetic pattern of oil degradation. The oil degradation was incomplete 40 months after the oil exposure, with a dissipation of $73 \%-92 \%$ of oil concentration. The result that the highest oil degradation rates occurred in bare fallow and lowest in fodder galega, disagrees with our hypothesis that the legume galega was expected to stimulate oil degradation owing to its BNF ability. Nevertheless, our results demonstrate the ecological and agronomic feasibility of planting a legume (fodder galega) and a grass (smooth brome) on oil-contaminated soil in a boreal climate, as both crops were oil-tolerant. The presence of oil, unexpectedly, enhanced the overall crop dry matter yield and $\mathrm{N}$ yield over years. In addition, oil enhanced the BNF efficiency of the legume. Fodder galega could fully replace $\mathrm{N}$ fertilizer for brome grass and enable a high dry matter production of the grass in the mixture plots, due to its substantial BNF ability. The inoculation of plant growth promoting bacteria had a minor effect on crop physiological properties, but significantly increased the BNF efficiency of the legume, especially in the mixture plots. The 
galega-bromus grass mixture residues can be converted into high-value fertilizer owing to the closeto-optimum $\mathrm{C}: \mathrm{N}$ ratio via microbial decomposition. Therefore, we suggest that the perennial legume-grass mixture, co-inoculated with appropriate rhizobia and PGPB, is a competitive and sustainable cropping system to alleviate soil contamination in boreal soils, with considerable economic value for bioenergy and bio-fertilizer production.

Factors influencing the efficiency of the boreal legume-cropping bioremediation system remain to be further identified. In subsequent work, molecular techniques such as NGS sequencing, microbial community fingerprinting techniques and functional gene analysis will be incorporated to identify the oil-degrading populations and the specific metabolic pathways with the aim to provide a comprehensive evaluation of the legume-cropping bioremediation system in a boreal region. Acknowledgements

This work was funded by Legume Futures, an international research project funded by the European Union through the Framework 7 Programme (FP7) under grant agreement number 245216 (FP7KBBE-2009-3), and by MUTKU ry for oil analysis. Tuula Puhakainen and Arja Nykänen are acknowledged for their contribution to the field data collection. We thank Markku Tykkyläinen for his technical assistance in the field management and plant harvest. The authors also acknowledge Anni-Mari Pulkkinen and Kati P. Pulkkinen for their technical assistance with oil analysis and Dr P.P.M. Iannetta and his colleagues at the James Hutton Institute for the ${ }^{15} \mathrm{~N}$ analysis of the plant samples.

\section{References}

Acharya, K. P., Shilpkar, P., Shah, M. C. \& Chellapandi, P. 2015. Biodegradation of insecticide Monocrotophos by Bacillus subtilis KPA-1, isolated from agriculture soils. Applied Biochemistry and Biotechnology 175: 1789-1804.

Adamovich, A., Adamovicha, O., Vliegher, A. d. \& Carlier, L. 2007. Forage quality dynamics and productivity of fodder galega-grass swards. Forage quality dynamics and productivity of fodder 
galega-grass swards. Permanent and temporary grassland: plant, environment and economy. Proceedings of the 14th Symposium of the European Grassland Federation, Ghent, Belgium, 3-5 September 2007. Belgian Society for Grassland and Forage Crops. pp. 181-184.

Adamovich, A. 2001. Productivity and yield quality of fodder galega (Galega orientalis Lam.) grass mixed swards. Plant Nutrition. Developments in Plant and Soil Sciences 92: 1008-1009.

Balba, M., Al-Awadhi, N. \& Al-Daher, R. 1998. Bioremediation of oil-contaminated soil: microbiological methods for feasibility assessment and field evaluation. Journal of microbiological methods 32: 155-164.

Bhattacharyya, P. N. \& Jha, D. K. 2012. Plant growth-promoting rhizobacteria (PGPR): emergence in agriculture. World Journal of Microbiology \& Biotechnology 28: 1327-1350.

Boopathy, R. 2000. Factors limiting bioremediation technologies. Bioresource technology 74: 6367.

Börner, F., Gruhne, M. \& Schön, J. 1993. Contamination indications derived from electrical properties in the low frequency RANGE1. Geophysical Prospecting 41: 83-98.

Bragg, J. R., Prince, R. C., Harner, E. J. \& Atlas, R. M. 1994. Effectiveness of bioremediation for the Exxon Valdez oil spill. Nature 368: 413-418.

Caravaca, F. \& Roldán, A. 2003. Assessing changes in physical and biological properties in a soil contaminated by oil sludges under semiarid Mediterranean conditions. Geoderma 117: 53-61.

Chiapusio, G., Pujol, S., Toussaint, M., Badot, P. \& Binet, P. 2007. Phenanthrene toxicity and dissipation in rhizosphere of grassland plants (Lolium perenne L. and Trifolium pratense L.) in three spiked soils. Plant and Soil 294: 103-112. 
Dexter, A. 2004. Soil physical quality: Part I. Theory, effects of soil texture, density, and organic matter, and effects on root growth. Geoderma 120: 201-214.

Egamberdieva, D., Berg, G., Lindström, K. \& Räsänen, L. 2010. Co-inoculation of Pseudomonas spp. with Rhizobium improves growth and symbiotic performance of fodder galega (Galega orientalis Lam.). European Journal of Soil Biology 46: 269-272.

Global Invasive Species Database. 2010. Bromus inermis (grass). http://www.issg.org/database/species/ecology.asp?si=1223. National Biological Information Infrastructure (NBII) \& IUCN/SSC Invasive Species Specialist Group (ISSG). Cited 07.12.2014.

Halling M.A., Hopkins A., Nissinen O., Paul C., Tuori M. and Sölter U. (2002) Forage legumes productivity and composition. In: WilkinsR.J. and PaulC. (eds) Legume silages for animal production-LEGSIL, Proceedings of an International Workshop, Braunschweig, 2001. Landbauforschung Völkenrode, Sonderheft 234, pp. 5-15. Braunschweig, Germany: FAL.

Hatzinger, P. B. \& Alexander, M. 1995. Effect of aging of chemicals in soil on their biodegradability and extractability. Environmental Science \& Technology 29: 537-545.

Huesemann, M. H. 1997. Incomplete hydrocarbon biodegradation in contaminated soils: limitations in bioavailability or inherent recalcitrance? Bioremediation Journal 1: 27-39.

ISO/DIS 16703:2004. Soil quality -- Determination of content of hydrocarbon in the range C10 to C40 by gas chromatography. ISO, Geneva Switzerland (2004).

Jasinskas, A., Zaltauskas, A. \& Kryzeviciene, A. 2008. The investigation of growing and using of tall perennial grasses as energy crops. Biomass and Bioenergy 32: 981-987.

Jørgensen, K., Järvinen, O., Sainio, P., Salminen, J. \& Suortti, A. 2005. Quantification of soil contamination. Monitoring and Assessing Soil Bioremediation. Springer. p. 97-119. 
Jørgensen, K., Puustinen, J. \& Suortti, A. 2000. Bioremediation of petroleum hydrocarboncontaminated soil by composting in biopiles. Environmental pollution 107: 245-254.

Jussila, M. M., Jurgens, G., Lindström, K. \& Suominen, L. 2006. Genetic diversity of culturable bacteria in oil-contaminated rhizosphere of Galega orientalis. Environmental pollution 139: 244257.

Kamath, R., Rentz, J., Schnoor, J. L. \& Alvarez, P. 2004. Phytoremediation of hydrocarboncontaminated soils: principles and applications. Studies in surface science and catalysis 151: 447478.

Kawasaki, A., Watson, E. R. \& Kertesz, M. A. 2012. Indirect effects of polycyclic aromatic hydrocarbon contamination on microbial communities in legume and grass rhizospheres. Plant and Soil 358: 169-182.

Kryževičienè, A., Jasinskas, A. \& Gulbinas, A. 2008. Perennial grasses as a source of bioenergy in Lithuania. Agronomy Research 6: 229-239.

Lättemäe, P., Meripõld, H., Tamm, U., Tamm, S., Helgadóttir, Á \& Hopkins, A. 2013. The effect of different fodder galega-grass mixtures and nitrogen fertilization on forage yield and chemical composition. The role of grasslands in a green future: threats and perspectives in less favoured areas. Proceedings of the 17th Symposium of the European Grassland Federation, Akureyri, Iceland, 23-26 June 2013. Agricultural University of Iceland. pp. 168-170.

Lindstrom, K., Jussila, M. M., Hintsa, H., Kaksonen, A., Mokelke, L., Makelainen, K., Pitkajarvi, J. \& Suominen, L. 2003. Potential of the Galega-Rhizobium galegae system for bioremediation of oilcontaminated soil. Food Technology and Biotechnology 41: 11-16. 
Lindström, K. 1984. Analysis of factors affecting in situ nitrogenase $\left(\mathrm{C}_{2} \mathrm{H}_{2}\right)$ activity of Galega orientalis, Trifolium pratense and Medicago sativa in temperate conditions. Plant and Soil 79: 329341.

Margesin, R. \& Schinner, F. 1997. Laboratory bioremediation experiments with soil from a dieseloil contaminated site — significant role of cold-adapted microorganisms and fertilizers. Journal of chemical technology and biotechnology 70: 92-98.

Mikkonen, A., Hakala, K.P., Lappi, K., Kondo, E., Vaalama, A. \& Suominen, L. 2012. Changes in hydrocarbon groups, soil ecotoxicity and microbiology along horizontal and vertical contamination gradients in an old landfarming field for oil refinery waste. Environmental Pollution 162: 374-380.

Mikkonen, A., Kondo, E., Lappi, K., Wallenius, K., Lindström, K., Hartikainen, H. \& Suominen, L. 2011. Contaminant and plant-derived changes in soil chemical and microbiological indicators during fuel oil rhizoremediation with Galega orientalis. Geoderma 160: 336-346.

Miya, R. K. \& Firestone, M. K. 2001. Enhanced phenanthrene biodegradation in soil by slender oat root exudates and root debris. Journal of environmental quality 30: 1911-1918.

Ndegwa, P. M. \& Thompson, S. 2000. Effects of C-to-N ratio on vermicomposting of biosolids. Bioresource technology 75: 7-12.

Nocentini, M., Pinelli, D. \& Fava, F. 2000. Bioremediation of a soil contaminated by hydrocarbon mixtures: the residual concentration problem. Chemosphere 41: 1115-1123.

Pajuelo, E., Rodríguez-Llorente, I. D., Lafuente, A. \& Caviedes, M. Á 2011. Legume-rhizobium symbioses as a tool for bioremediation of heavy metal polluted soils. Biomanagement of MetalContaminated Soils. Environmental Pollution 20: 95-123. 
Pyy, O., Haavisto, T., Niskala, K. \& Silvola, M. 2013. Contaminated land in Finland - Report 2013. Reports of the Finnish Environment Institute 27/2013, 57 p. in Finnish, English abstract. ISBN 978952-11-4219-2.

Radwan, S., Sorkhoh, N. \& El-Nemr, I. 1995. Oil biodegradation around roots. Nature 376: 302.

Rentz, J. A., Alvarez, P. J. \& Schnoor, J. L. 2005. Benzo [a] pyrene co-metabolism in the presence of plant root extracts and exudates: Implications for phytoremediation. Environmental Pollution 136: $477-484$.

Sarkar, D., Ferguson, M., Datta, R. \& Birnbaum, S. 2005. Bioremediation of petroleum hydrocarbons in contaminated soils: comparison of biosolids addition, carbon supplementation, and monitored natural attenuation. Environmental pollution 136: 187-195.

Sienkiewicz, S., Zarczynski, P. \& Krzebietke, S. 2011. Effect of land use of fields excluded from cultivation on soil content of available nutrients. Journal of Elementology 16(1): 75-84.

Singer, A. C., Crowley, D. E. \& Thompson, I. P. 2003. Secondary plant metabolites in phytoremediation and biotransformation. Trends in Biotechnology 21: 123-130.

Snoeyink, V. L. \& Jenkins, D. 1980. Water chemistry. John Wiley.

Suominen, L., Jussila, M., Mäkeläinen, K., Romantschuk, M. \& Lindström, K. 2000. Evaluation of the Galega-Rhizobium galegae system for the bioremediation of oil-contaminated soil. Environmental Pollution 107: 239-244.

Unkovich, M. J. \& Pate, J. S. 2000. An appraisal of recent field measurements of symbiotic $\mathrm{N}_{2}$ fixation by annual legumes. Field Crops Research 65: 211-228. 
Unkovich, M., Herridge, D., Peoples, M., Cadisch, G., Boddey, B., Giller, K., Alves, B. \& Chalk, P. 2008. Measuring plant-associated nitrogen fixation in agricultural systems. Australian Centre for International Agricultural Research (ACIAR), Canberra, Australia, in press.

Van Gestel, K., Mergaert, J., Swings, J., Coosemans, J. \& Ryckeboer, J. 2003. Bioremediation of diesel oil-contaminated soil by composting with biowaste. Environmental Pollution 125: 361-368.

Vershinina, Z. R., Baymiev, A. K., Blagova, D. K., Chubukova, O. V., Baymiev, A. K. \& Chemeris, A. V. 2012. Artificial colonization of non-symbiotic plants roots with the use of lectins. Symbiosis 56: 25-33.

Wang, Z., \& Fingas, M. 1997. Developments in the analysis of petroleum hydrocarbons in oils, petroleum products and oil-spill-related environmental samples by gas chromatography. Journal of Chromatography A, 774(1): 51-78.

Wenzel, W. W. 2009. Rhizosphere processes and management in plant-assisted bioremediation (phytoremediation) of soils. Plant and Soil 321: 385-408.

Wuest, S. 2014. Seasonal variation in soil organic carbon. Soil Science Society of America Journal 78: $1442-1447$.

Zolotarev, V. 2010. Agroecological estimate of sowing times of fodder galega for seeds in the central region of Russia. Russian Agricultural Sciences 36: 433-436. 
Tables

Table 1. General information about the experimental field

\begin{tabular}{ll}
\hline Site properties & Details \\
\hline Site area & $420 \mathrm{~m}^{2}$ \\
Plot size & $3.75 \mathrm{~m}^{2}(2.5 \mathrm{~m} \times 1.5 \mathrm{~m})$ \\
Soil structure & Clay loam (on average, $32 \%$ clay, $36 \%$ silt, 32\% sand) \\
Altitude & $8 \mathrm{~m}$ \\
Vegetation zone & Boreal \\
Annual precipitation & $650 \mathrm{~mm}$ \\
Annual mean temperature & $4.9^{\circ} \mathrm{C}$ \\
Farming systems & Integrated \\
Cropping history & Salix \\
\hline
\end{tabular}


Table 2. Monthly average temperature $\left({ }^{\circ} \mathrm{C}\right)$ and total precipitation $(\mathrm{mm})$ during the growing season in Helsinki for the experimental period May - Oct. (2009-2012) compared with the long term data (1971-2000), provided by Finnish Meteorological Institute.

\begin{tabular}{|c|c|c|c|c|c|c|c|c|c|c|c|}
\hline \multirow[t]{2}{*}{ Month } & \multicolumn{5}{|c|}{ Average temperature $\left({ }^{\circ} \mathrm{C}\right)$} & & \multicolumn{5}{|c|}{ Precipitation (mm) } \\
\hline & $1971-2000$ & 2009 & 2010 & 2011 & 2012 & & $\begin{array}{l}1971-2000 \\
\end{array}$ & 2009 & 2010 & 2011 & 2012 \\
\hline May & 9.8 & 11.0 & 11.5 & 9.9 & 10.9 & & 37 & 45 & 59 & 27 & 65 \\
\hline June & 14.8 & 14.1 & 14.6 & 16.7 & 13.7 & & 57 & 75 & 33 & 49 & 88 \\
\hline July & 17.2 & 17.2 & 21.7 & 20.6 & 17.7 & & 63 & 131 & 49 & 56 & 54 \\
\hline August & 15.8 & 16.7 & 18.1 & 17.5 & 16.0 & & 80 & 49 & 97 & 173 & 39 \\
\hline September & 10.9 & 13.5 & 12.2 & 13.6 & 12.5 & & 56 & 40 & 50 & 88 & 160 \\
\hline October & 6.2 & 4.2 & 6.0 & 8.5 & 6.7 & & 76 & 90 & 29 & 69 & 93 \\
\hline Average & 12.5 & 12.8 & 14.0 & 14.5 & 12.9 & Total & 369 & 429 & 312 & 460 & 499 \\
\hline
\end{tabular}


Table 3. Information on soil sampling

\begin{tabular}{llll}
\hline Year & Growing season & Date & No. of samples \\
\hline 2009 & Crop & July 16-17 & 64 \\
2010 & Beginning & May 17-25 & 64 \\
2010 & End & November 12 & 64 \\
2011 & Beginning & May 17-19 & 64 \\
2012 & Beginning & May 21 & 32 (PGPB-untreated plots) \\
2012 & End & October 11 & 32 (PGPB-untreated plots) \\
\hline
\end{tabular}


Table 4. Crop physiological properties during the experimental years, with significance of terms from repeated measures ANOVA

\begin{tabular}{|c|c|c|c|c|c|c|c|c|c|c|c|c|c|c|c|c|c|}
\hline \multirow[t]{2}{*}{ Treatment } & & \multicolumn{4}{|c|}{ SPAD readings } & \multicolumn{3}{|c|}{ Crop C\% } & \multicolumn{4}{|c|}{ Crop N\% } & \multicolumn{5}{|c|}{ Crop C:N ratio } \\
\hline & & 2010 & 2011 & 2012 & Mean & 2010 & 2011 & 2012 & Mean & 2010 & 2011 & 2012 & Mean & 2010 & 2011 & 2012 & Mean \\
\hline Brome grass & & 33.6 & 28.6 & 27.6 & $29.9^{c}$ & 44.5 & 44.2 & 43.0 & $43.9^{b}$ & 1.6 & 1.3 & 1.4 & $1.4^{c}$ & 28.3 & 33.9 & 32.3 & $31.5^{a}$ \\
\hline Galega & & 33.0 & 38.0 & 40.1 & $37.0^{a}$ & 45.0 & 46.1 & 44.7 & $45.2^{a}$ & 2.7 & 3.2 & 3.5 & $3.1^{a}$ & 17.0 & 14.4 & 13.0 & $14.8^{c}$ \\
\hline \multirow[t]{2}{*}{ Mixture } & & 32.9 & 30.7 & 30.5 & $31.4^{b}$ & 44.5 & 44.2 & 43.4 & $44.0^{b}$ & 1.9 & 1.5 & 1.7 & $1.7^{b}$ & 24.1 & 30.8 & 26.3 & $27.0^{b}$ \\
\hline & SEM & 0.4 & 0.3 & 0.5 & 0.3 & 0.0 & 0.3 & 0.1 & 0.1 & 0.1 & 0.02 & 0.03 & 0.02 & 0.6 & 0.3 & 0.3 & 0.2 \\
\hline
\end{tabular}

Tests of Between-Subjects Effects

Source df significance level

$\begin{array}{lllll}\text { crop } & 2 & * * * & * * * & * * *\end{array}$

Tests of Within-Subjects Effects (Sphericity Assumed)

Source df significance level

time $\quad 2$

time $\times$ crop $4 \quad * * *$

time $\times$ crop $\times$ oil 4

* ns

$\begin{array}{lll}* * * & * * & * * * \\ * & * * * & * * * \\ n s & n s & n s\end{array}$

$\overline{S E M}$ standard error of mean, $d f$ degrees of freedom, $n s$ not significant, ${ }^{*} p<0.05, * * p<0.01$ and ${ }^{* * *} p<0.001$. The tests were based on split-plot-based repeated measures (RM) ANOVA model: $Y_{l}=$ residue $($ error $)+$ crop + crop $\times$ replicate + oil + PGPB + oil $\times$ PGPB + oil $\times$ crop + crop $\times$ PGPB + oil $\times$ crop $\times$ PGPB, with time as the repeated factor. The 
factors or interactions that had no significant effects on soil physiological parameters are not presented in this table. The italic numbers refer to the average values (as well as the

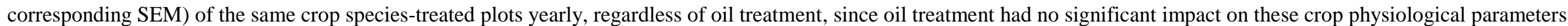

Different uppercase letters ( $\mathrm{a}, \mathrm{b}$ and $\mathrm{c})$ indicate significant differences $(p<0.05)$ between the means of crop treatments based on Tukey HSD multiple comparison test. 
Table 5. Annual dry matter and $\mathrm{N}$ yields in the experimental treatments, with significance of terms from the analysis of variance

\begin{tabular}{|c|c|c|c|c|c|c|c|c|c|c|}
\hline \multicolumn{2}{|l|}{ Treatment } & & \multicolumn{4}{|c|}{ Dry matter yield, $\mathrm{Mg} \mathrm{ha}^{-1}$} & \multicolumn{4}{|c|}{ Crop N yield, $\mathrm{kg} \mathrm{ha}^{-1}$} \\
\hline Crop & Oil & & 2010 & 2011 & 2012 & Mean & 2010 & 2011 & 2012 & Mean \\
\hline \multirow[t]{2}{*}{ Brome grass } & -oil & & 6.85 & 7.38 & 7.02 & 7.09 & 106 & 94 & 100 & 100 \\
\hline & +oil & & 7.61 & 7.58 & 7.55 & 7.58 & 111 & 96 & 102 & 104 \\
\hline \multirow[t]{2}{*}{ Galega } & - oil & & 3.95 & 9.06 & 8.55 & 7.19 & 117 & 289 & 293 & 233 \\
\hline & +oil & & 4.65 & 10.01 & 9.87 & 8.18 & 140 & 323 & 353 & 272 \\
\hline \multirow[t]{3}{*}{ Mixture } & -oil & & 7.92 & 11.25 & 9.32 & 9.50 & 149 & 167 & 150 & 156 \\
\hline & +oil & & 8.90 & 11.12 & 10.22 & 10.08 & 182 & 150 & 178 & 170 \\
\hline & & SEM & 0.29 & 0.37 & 0.39 & 0.28 & 12 & 10 & 7 & 7 \\
\hline
\end{tabular}

Tests of Between-Subjects Effects

\begin{tabular}{|c|c|c|c|c|c|c|c|c|c|}
\hline Source & df & signi & ican & evel & & & & & \\
\hline crop & 2 & $* * *$ & $* *$ & $* *$ & $* *$ & $* *$ & $* * *$ & $* * *$ & $* * *$ \\
\hline oil & 1 & $* *$ & $\mathrm{~ns}$ & $* *$ & $* *$ & ns & $\mathrm{ns}$ & $* * *$ & $* *$ \\
\hline PGPB & 1 & ns & ns & ns & $n s$ & $\mathrm{~ns}$ & $\mathrm{~ns}$ & $* *$ & $n s$ \\
\hline crop $\times$ oil & 2 & $\mathrm{~ns}$ & ns & ns & $n s$ & ns & $*$ & $* *$ & $n s$ \\
\hline
\end{tabular}

Tests of Within-Subjects Effects (Sphericity Assumed) 


$\begin{array}{lccc}\text { Source } & \text { df } & \text { significance level } & \\ \text { time } & 2 & * * * & * * * \\ \text { time } \times \text { crop } & 4 & * * * & * * * \\ \text { time } \times \text { oil } & 2 & n s & * \\ \text { time } \times \text { crop } \times \text { oil } \times \text { PGPB } & 4 & * & n s\end{array}$

$\overline{S E M}$ standard error of the means; $d f$ degrees of freedom, $n s$ not significant, $* p<0.05, * * p<0.01$ and $* * * p<0.001$. The tests of Between-Subjects and Within-Subjects Effects were based on split-plot-based repeated measures $(\mathrm{RM})$ ANOVA model: $Y_{l}=$ residue $($ error $)+$ crop + crop $\times$ replicate + oil + PGPB + oil $\times$ PGPB + oil $\times$ crop + crop $\times$ PGPB + oil $\times$ crop $\times$ PGPB, with time as the repeated factor. The results of RM ANOVA are shown under the column of means. Because some of the interactions with time were significant, split-plot univariate (UV) ANOVA was conducted on each year's individual results. The factors or interactions that had no significant effects on the tested parameters are not presented in this table. 
Table 6. The \%Ndfa, BNF yield and the BNF yield / DM yield in galega above-ground dry matter in 2010-2012, with significance of terms from the analysis of variance

\begin{tabular}{|c|c|c|c|c|c|c|c|c|c|c|c|c|c|c|}
\hline \multicolumn{3}{|c|}{ Treatment } & \multicolumn{4}{|c|}{ Shoot \%Ndfa } & \multicolumn{4}{|c|}{ Shoot BNF yield, $\mathrm{kg} \mathrm{ha}^{-1}$} & \multicolumn{4}{|c|}{ BNF yield / galega DM yield, $\mathrm{g} \mathrm{kg}^{-1}$} \\
\hline Crop & Oil & & 2010 & 2011 & 2012 & Mean & 2010 & 2011 & 2012 & Mean & 2010 & 2011 & 2012 & Mean \\
\hline \multirow[t]{2}{*}{ Galega } & - oil & & 65.4 & 61.2 & 70.6 & 65.7 & 69.8 & 177.1 & 186.6 & 144.5 & 18.8 & 19.4 & 23.4 & 20.5 \\
\hline & +oil & & 59.5 & 52.8 & 72.0 & 61.4 & 68.6 & 159.7 & 249.4 & 159.2 & 17.0 & 16.9 & 26.0 & 20.0 \\
\hline \multirow[t]{3}{*}{ Mixture } & - oil & & 69.7 & 70.3 & 83.4 & 74.5 & 19.3 & 7.4 & 23.5 & 16.7 & 21.5 & 21.9 & 35.6 & 26.3 \\
\hline & +oil & & 68.7 & 63.4 & 84.2 & 72.1 & 17.5 & 6.2 & 36.5 & 20.0 & 22.8 & 20.7 & 45.5 & 29.7 \\
\hline & & SEM & 4.4 & 1.9 & 0.2 & 1.2 & 5.9 & 7.6 & 8.5 & 5.7 & 2.1 & 1.0 & 1.0 & 1.2 \\
\hline
\end{tabular}

Tests of Between-Subjects Effects

\begin{tabular}{|c|c|c|c|c|c|c|c|c|c|c|c|c|c|}
\hline Source & df & sig & ice 1 & & & & & & & & & & \\
\hline crop & 1 & ns & ns & $*$ & $p=0.051$ & ns & $\mathrm{ns}$ & $*$ & $* * *$ & ns & ns & $* *$ & $*$ \\
\hline oil & 1 & ns & $* *$ & $* *$ & * & ns & $\mathrm{ns}$ & $* *$ & $n s$ & ns & ns & ns & $n s$ \\
\hline crop $\times$ oil & 1 & ns & ns & ns & $n s$ & ns & ns & $* *$ & $n s$ & ns & ns & ns & $n s$ \\
\hline
\end{tabular}

Tests of Within-Subjects Effects (Sphericity Assumed)

Source df significance level

time 2

time $\times$ crop $\quad 2$

**

$n s$

$* * *$
$* * *$

$* *$

$n s$ 


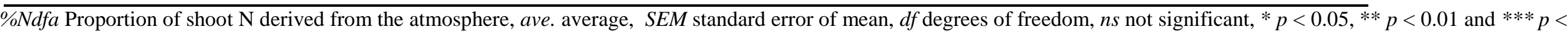

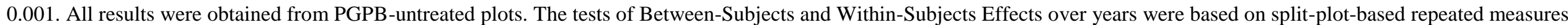

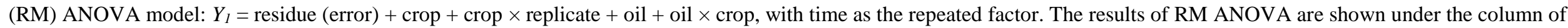
means. Because some of the interactions with time were significant, split-plot univariate (UV) ANOVA was conducted on each year's individual results. 
Table 7. PGPB effect on the nitrogen fixation efficiency of the legume-cropping systems in both cuts of 2010, with significance of terms from the analysis of variance

\begin{tabular}{|c|c|c|c|c|c|c|c|c|}
\hline \multicolumn{2}{|c|}{ Treatment } & & \multicolumn{3}{|l|}{$\%$ Ndfa } & \multicolumn{3}{|c|}{ BNF yield, $\mathrm{kg} \mathrm{ha}^{-1}$} \\
\hline PGPB & Crop & & 1 st cut & 2nd cut & 2010 & 1 st cut & 2nd cut & 2010 \\
\hline \multirow[t]{2}{*}{ PGPB- } & Galega & & 69.9 & 38.5 & 62.4 & 58.7 & 10.6 & 69.2 \\
\hline & Mixture & & 70.1 & 52.3 & 69.2 & 18.0 & 0.4 & 18.4 \\
\hline \multirow[t]{3}{*}{ PGPB+ } & Galega & & 70.4 & 42.6 & 66.0 & 84.8 & 10.0 & 94.8 \\
\hline & Mixture & & 83.6 & 68.4 & 83.0 & 26.1 & 0.7 & 26.7 \\
\hline & & SEM & 2.7 & 4.4 & 2.6 & 3.4 & 0.7 & 3.8 \\
\hline \multicolumn{2}{|l|}{ Source } & $\overline{d f}$ & \multicolumn{6}{|c|}{ significance level } \\
\hline crop & & 1 & $\mathrm{~ns}$ & $* * *$ & $n s$ & $* * *$ & $* * *$ & $* * *$ \\
\hline oil & & 1 & ns & $*$ & $n s$ & ns & $* *$ & $n s$ \\
\hline PGPB & & 1 & $*$ & $*$ & $* *$ & $* * *$ & $\mathrm{~ns}$ & $* * *$ \\
\hline \multicolumn{2}{|c|}{ crop $\times$ oil } & 1 & $\mathrm{~ns}$ & $*$ & $n s$ & ns & $* *$ & $n s$ \\
\hline \multicolumn{2}{|c|}{ crop $\times$ PGPB } & 1 & $*$ & ns & $n s$ & $*$ & ns & * \\
\hline
\end{tabular}

$\% N d f a$ the proportion of $\mathrm{N}$ derived from atmospheric $\mathrm{N}_{2}, B N F$ yield the $\mathrm{N}$ yield that was biologically fixed into the legume shoot from atmospheric $\mathrm{N}_{2}, S E M$ standard error of mean, $d f$ degrees of freedom, $n s$ not significant, $* p<0.05$, $* * p<0.01$ and $* * * p<0.001$. The italic numbers refer to the calculated annual values (not the average values between both cuts) as well as the corresponding SEM under the same PGPB treatment, regardless of oil treatment. Tests of Between-Subjects Effects were performed based on the split-plot-based univariate (UV) ANOVA model: $Y_{l}=$ residue (error) + crop + crop $\times$ replicate + oil + PGPB + oil $\times$ PGPB + oil $\times$ crop + crop $\times$ PGPB + oil $\times$ crop $\times$ PGPB The factors or interactions that had no significant effects on the test parameters are not presented in this table. 
Table 8. Changes of soil chemical properties in regard to oil contamination over years, with significance of terms from the repeated measures ANOVA based on a split-plot experimental design

\begin{tabular}{|c|c|c|c|c|c|c|c|}
\hline Treatment & Sampling time & $\mathrm{pH}$ & & $\mathrm{EC}, \mu \mathrm{S} \mathrm{cm}^{-1}$ & Total $\mathrm{C}, \mathrm{g} \mathrm{kg}^{-1}$ & Total $\mathrm{N}, \mathrm{g} \mathrm{kg}^{-1}$ & $\mathrm{C}: \mathrm{N}$ ratio \\
\hline \multirow[t]{3}{*}{- oil } & July 2009 & $6.48(0.02)$ & $6.35(0.02)$ & $79.9(1.96) 66.6(1.4)$ & $23.89(0.36) \quad 23.78(0.21)$ & $2.21(0.05) 2.22(0.02)$ & $10.9(0.2) \quad 10.8(0.1)$ \\
\hline & Nov. 2010 & $6.35(0.02)$ & & $63.7(2.06)$ & $24.34(0.40)$ & $2.28(0.04)$ & $10.7(0.2)$ \\
\hline & May 2012 & $6.22(0.03)$ & & $56.2(1.84)$ & $23.11(0.16)$ & $2.15(0.02)$ & $10.7(0.1)$ \\
\hline \multirow[t]{3}{*}{ +oil } & July 2009 & $6.53(0.02)$ & $6.39(0.02)$ & $51.6(1.96) \quad 54.9(1.4)$ & $27.85(0.36) \quad 26.07(0.21)$ & $2.23(0.05) \quad 2.21(0.02)$ & $12.5(0.2) \quad 11.8(0.1)$ \\
\hline & Nov. 2010 & $6.39(0.02)$ & & $54.1(2.06)$ & $25.67(0.40)$ & $2.21(0.04)$ & $11.7(0.2)$ \\
\hline & May 2012 & $6.26(0.03)$ & & $54.4(1.84)$ & $24.68(0.16)$ & $2.19(0.02)$ & $11.2(0.1)$ \\
\hline
\end{tabular}

Tests of Between-Subjects Effects

\begin{tabular}{|c|c|c|c|c|c|c|}
\hline Source & $\mathrm{df}$ & sig & & & & \\
\hline crop & 3 & $n s$ & $n s$ & $n s$ & $n s$ & $n s$ \\
\hline oil & 1 & $n s$ & $* * *$ & $* * *$ & $n s$ & $* * *$ \\
\hline oil*crop & 3 & $*$ & $n s$ & $n s$ & $n s$ & * \\
\hline
\end{tabular}

Tests of Within-Subjects Effects (Sphericity Assumed)

Source $\quad$ df $\quad$ significance level

time

$2 \quad * * *$

***

$* * *$

ns

$* *$ 
\begin{tabular}{llllll} 
time $\times$ crop & 6 & $n s$ & $*$ & $n s$ & $n s$ \\
time $\times$ oil & 2 & $n s$ & $* * *$ & $n s$ & $* *$ \\
time $\times$ crop $\times$ oil & 6 & $n s$ & $n s$ & $n s$ & $n s$ \\
\hline
\end{tabular}

with standard error of the means (SEM) presented in brackets. The italic numbers refer to the mean values (as well as SEM) of the parameters averaged between years in the presence or absence of oil treatment, regardless of cropping systems 
1 Table 9. Comparison of correlation coefficients for first-and second-order linear models for oil

2 degradation in bare fallow, pure brome grass-, pure galega- and mixture-cropped soils

Matrix $\quad$ First-order linear model $\mathrm{R}^{2}$ df $\quad$ Second-order linear model $\mathrm{R}^{2}$ df

\begin{tabular}{lllll}
\hline Bare fallow & $0.461 * * *$ & 25 & 0.000 & 27 \\
Brome grass & $0.571^{* * * *}$ & 26 & 0.066 & 27 \\
Galega & $0.521^{* * * *}$ & 27 & $0.436^{* * *}$ & 27 \\
Mixture & $0.379 * * *$ & 27 & $0.146^{*}$ & 27 \\
\hline$d f$ degrees of freedom, $* p<0.05, * * * p<0.001$ & &
\end{tabular}

$3 \quad d f$ degrees of freedom, ${ }^{*} p<0.05, * * * p<0.001$

4 
5 Table 10. Degradation coefficient $(k)$, half-life and regression equations for oil degradation in bare

6 fallow, pure brome grass-, pure galega- and mixture-cropped soils

Crop treatment $k\left(\right.$ month $\left.^{-1}\right)$ Half-life (months) Regression equations

\begin{tabular}{lccc}
\hline Bare fallow & 0.048 & 15 & $\mathrm{Y}_{\mathrm{BF}}=4.51 \mathrm{e}^{-0.048 \mathrm{t}}$ \\
Brome grass & 0.030 & 23 & $\mathrm{Y}_{\mathrm{B}}=5.26 \mathrm{e}^{-0.030 \mathrm{t}}$ \\
Galega & 0.029 & 24 & $\mathrm{Y}_{\mathrm{G}}=5.15 \mathrm{e}^{-0.029 \mathrm{t}}$ \\
Mixture & 0.042 & 16 & $\mathrm{Y}_{\mathrm{M}}=4.99 \mathrm{e}^{-0.042 \mathrm{t}}$ \\
& & & \\
\hline
\end{tabular}

7 
Supplementary materials

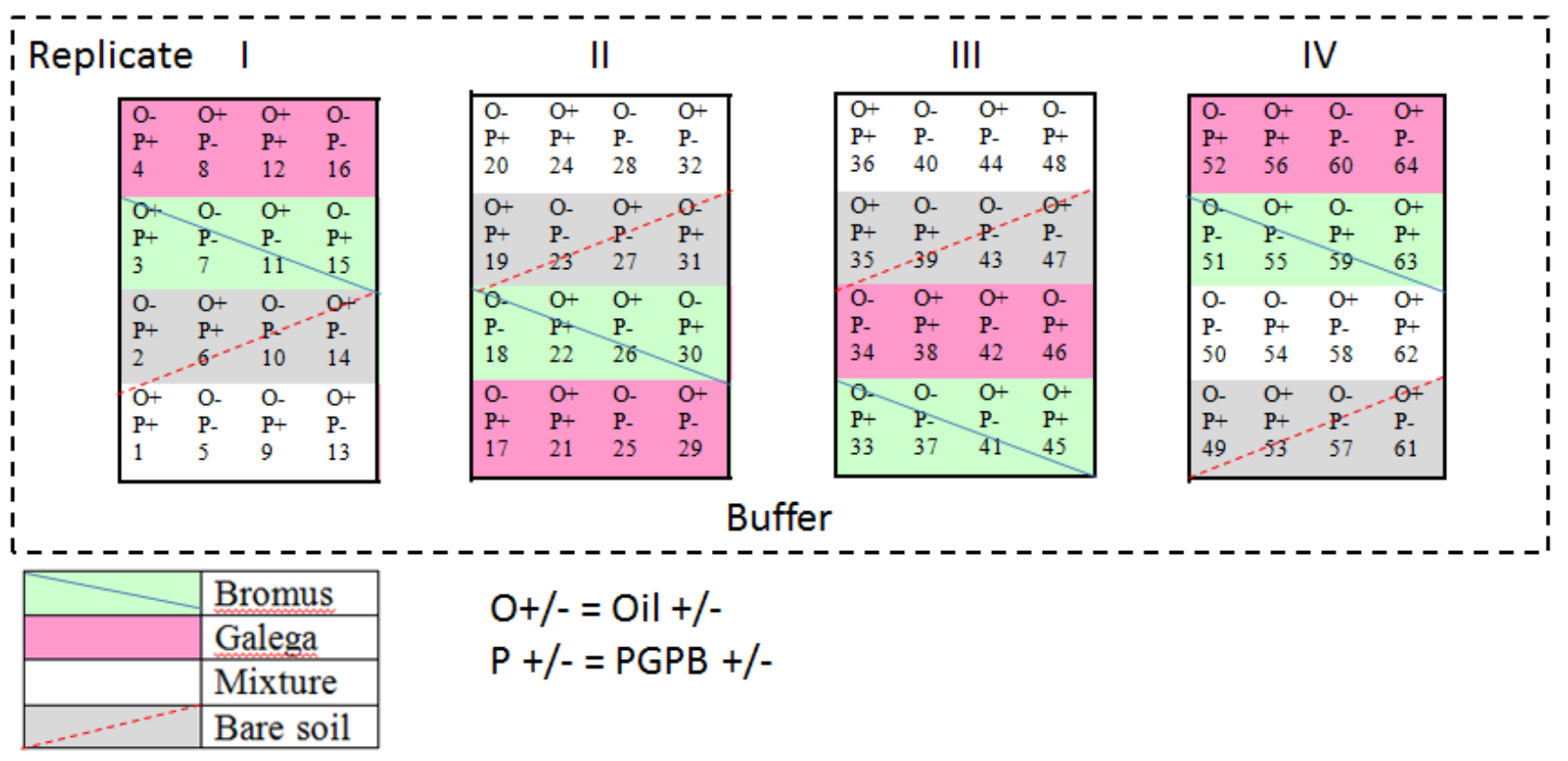

9

Figure S1. Layout of the field experiment, showing species, oil and PGPB treated plots. Numbers 11 are plot codes. 